Article

\title{
Application of the $\mathrm{NO}_{x}$ Reaction Model for Development of

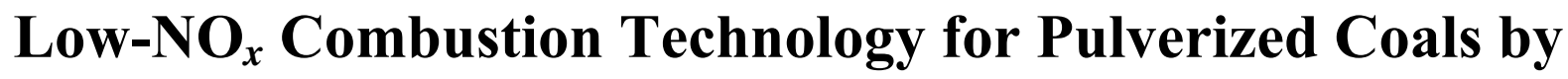 Using the Gas Phase Stoichiometric Ratio Index
}

\author{
Masayuki Taniguchi *, Yuki Kamikawa, Tsuyoshi Shibata, Kenji Yamamoto and \\ Hironobu Kobayashi
}

Energy and Environmental Systems Laboratory, Hitachi, Ltd. Power Systems Company, 7-2-1 Omika-cho, Hitachi-shi, Ibaraki-ken, 319-1292, Japan;

E-Mails: yuki.kamikawa.cg@hitachi.com (Y.K.); tsuyoshi.shibata.ae@hitachi.com (T.S.); kenji.yamamoto.va@hitachi.com (K.Y.); hironobu.kobayashi.gh@hitachi.com (H.K.)

* Author to whom correspondence should be addressed;

E-Mail: masayuki.taniguchi.xc@hitachi.com; Tel.: +81-29-276-5889.

Received: 9 December 2010; in revised form: 14 February 2011 / Accepted: 16 March 2011 / Published: 23 March 2011

\begin{abstract}
We previously proposed the gas phase stoichiometric ratio (SRgas) as an index to evaluate $\mathrm{NO}_{x}$ concentration in fuel-rich flames. The SRgas index was defined as the amount of fuel required for stoichiometric combustion/amount of gasified fuel, where the amount of gasified fuel was the amount of fuel which had been released to the gas phase by pyrolysis, oxidation and gasification reactions. In the present study we found that SRgas was a good index to consider the gas phase reaction mechanism in fuel-rich pulverized coal flames. When SRgas $<1.0, \mathrm{NO}_{x}$ concentration was strongly influenced by the SRgas value. $\mathrm{NO}_{x}$ concentration was also calculated by using a reaction model. The model was verified for various coals, particle diameters, reaction times, and initial oxygen concentrations. The most important reactions were gas phase $\mathrm{NO}_{x}$ reduction reactions by hydrocarbons. The hydrocarbon concentration was estimated based on SRgas. We also investigated the ratio as an index to develop a new low- $\mathrm{NO}_{x}$ combustion technology for pulverized coals. We examined the relation between local SRgas distribution in the fuel-rich region in the low- $\mathrm{NO}_{x}$ flame and $\mathrm{NO}_{x}$ emissions at the furnace exit, by varying burner structures. The relationship between local SRgas value and local $\mathrm{NO}_{x}$ concentration was also examined. When a low- $\mathrm{NO}_{x}$ type burner was used, the value of SRgas in the flame was readily decreased. When the local SRgas value was the same, it was difficult to influence the local
\end{abstract}


$\mathrm{NO}_{x}$ concentration by changing the burner structure. For staged combustion, the most important item was to design the burner structure and arrangement so that SRgas could be lowered as much as possible just before mixing with staged air.

Keywords: low- $\mathrm{NO}_{x}$ combustion; pulverized coals; $\mathrm{NO}_{x}$ reduction; gas phase stoichiometric ratio; hydrocarbons

\section{Nomenclature:}

$E$ : activation energy $(\mathrm{J} / \mathrm{mol})$;

$k$ : frequency factor;

$L$ : distance between the burner nozzle and sampling port (mm);

$n$ : constant;

$\left[\mathrm{NO}_{x}\right]$ : concentration of $\mathrm{NO}_{x}\left(\mathrm{~mol} / \mathrm{m}^{3}\right)$;

$[\mathrm{OH}]$ : concentration of $\mathrm{OH}\left(\mathrm{mol} / \mathrm{m}^{3}\right)$;

$\left[\mathrm{OH}_{\mathrm{eq}}\right]$ : equilibrium concentration of $\mathrm{OH}$ $\left(\mathrm{mol} / \mathrm{m}^{3}\right)$;

$\mathrm{Ox}(\mathrm{OH})$ : oxidative species, such as $\mathrm{OH}$;

$P_{\mathrm{O}_{2}}$ : partial pressure of oxygen $(\mathrm{Pa})$;

$\mathrm{P}_{\mathrm{CO}_{2}}$ : partial pressure of carbon dioxide $(\mathrm{Pa})$;

$P_{\mathrm{H}_{2} \mathrm{O}}$ : partial pressure of water $(\mathrm{Pa})$;

$R$ : gas constant, $8.314 \mathrm{~J} / \mathrm{K} \mathrm{mol}$;

$S$ : total surface area of coal or char

$\left(\mathrm{m}^{2} / \mathrm{kg}\right.$-total gas);

$S$ ': total surface area of coal or char

$\left(\mathrm{m}^{2} / \mathrm{m}^{3}\right.$-total gas);
SRin: inlet stoichiometric ratio;

SRgas: gas phase stoichiometric ratio;

$T$ : gas temperature $(\mathrm{K})$;

$X$ : axial location $(\mathrm{mm})$;

$X_{\mathrm{CO}}$ : mole fraction of carbon monoxide;

$X_{\mathrm{CH} 4}$ : mole fraction of methane;

$X_{\mathrm{H}_{2}}$ : mole fraction of hydrogen;

$X_{\mathrm{O}_{2}}$ : mole fraction of oxygen;

$X_{\mathrm{O}_{2} 0}$ : mole fraction of oxygen in

combustion supporting gas;

$\mathrm{XN}\left(\mathrm{NH}_{3}, \mathrm{HCN}\right)$ : nitrogenous species;

$[\mathrm{XN}]$ : concentration of $\mathrm{XN}\left(\mathrm{mol} / \mathrm{m}^{3}\right)$;

[XNradical]: concentration of XNradical

$\left(\mathrm{mol} / \mathrm{m}^{3}\right)$;

$X_{\mathrm{THC}}$ : mole fraction of total hydrocarbons;

$X_{\mathrm{TR}}$ : mole fraction of tracer;

$X_{\mathrm{TR} 0}$ : mole fraction of tracer in

combustion supporting gas

\section{Introduction}

The implementation of low- $\mathrm{NO}_{x}$-combustion technologies for pulverized coals began in the 1980s [1]. Low $\mathrm{NO}_{x}$ combustion technologies have included two-stage combustion [2], re-burning [2,3], and in-flame $\mathrm{NO}_{x}$ reduction by using a low- $\mathrm{NO}_{x}$ burner [1,4]. A feature which is common to all these technologies is that the $\mathrm{NO}_{x}$ reduction region was formed in the flame where the oxygen concentration was very low [1]. To predict $\mathrm{NO}_{x}$ emissions well, it is important to be able to reliably predict $\mathrm{NO}_{x}$ concentrations in the $\mathrm{NO}_{x}$ reduction region. However, for combustion of coal, $\mathrm{NO}_{x}$ reduction performance changes easily with the burning conditions, such as coal properties [3] and coal particle diameter. However, boiler design and development cannot be done efficiently if it is necessary to change the method of $\mathrm{NO}_{x}$ reduction for each coal property. In a previous study, we proposed an index to estimate $\mathrm{NO}_{x}$ reduction performance [5]. This index has hardly any influence from the burning conditions. In the present study, we introduce a case which utilizes the proposed index to develop a new low- $\mathrm{NO}_{x}$-combustion technology. 
As computers have become even more sophisticated, their use to perform the numerical analyses needed in designing pulverized coal firing boilers is increasing [6-11]. The reduction of the computational load is important for engineering design of actual boilers, and this can be done by using appropriate models based on our proposed index.

Several studies have been made to investigate the reaction of volatile matter [12,13]. These studies focused on the first half of the coal combustion phenomenon. Other studies have focused on the second half of the coal combustion, the char combustion region [14,15]. While studies on $\mathrm{NO}_{x}$ reduction by char [16-19] have been made, the contribution for total $\mathrm{NO}_{x}$ emission from the pulverized coal combustion was not clear. In previous studies, we proposed a $\mathrm{NO}_{x}$ reaction model which focused on the gas phase reaction in the char combustion region $[5,15]$. A key reaction was reduction of $\mathrm{NO}_{x}$ by hydrocarbons. In the present study, the model was verified for various coals, particle diameters, reaction times, and initial oxygen concentrations.

\section{Results and Discussion}

\subsection{The Relationship between Gas Phase Stoichiometric Ratio, SRgas, and $N O_{\mathrm{x}}$}

Previously, we evaluated $\mathrm{NO}_{x}$ generation characteristics for the fuel-rich condition in an experiment which used a drop-tube furnace [15]. Under these conditions the $\mathrm{NO}_{x}$ characteristics seemed to depend on the burning conditions. Then, we analyzed the experimental data in the relationship between inlet stoichiometric ratio (SRin) and $\mathrm{NO}_{x}$ and this result depended on the coal properties, particle diameter, and burning temperature. SRin was defined as the stoichiometric ratio of inlet mixture of coal and air as shown in Equation (1) [5]:

SRin = amount of fuel required for stoichiometric combustion/amount of fuel actually supplied (1)

For pulverized coal combustion $\mathrm{NO}_{x}$ is reduced by both gas phase and solid phase reactions $[5,15]$. We tried to analyze the experimental data in reference [15] by separating them into gas phase and solid phase reactions; we focused especially on the gas phase reaction.

Figure 1 shows how to obtain the value of SRgas. Before combustion, all fuel components of the pulverized coals are in the solid phase. Pulverized coal particles are surrounded by a combustion supporting gas such as air.

After the coal particles are ignited, some of the fuel components move from the solid phase to the gas phase by pyrolysis, oxidation, and gasification reactions (Figure 1). The remaining fuel components stay in the solid phase. The gas phase stoichiometric ratio is the index which focuses on the amount of fuel components moving from the solid phase to the gas phase. We define the gas phase stoichiometric ratio (SRgas) by Equation (2):

SRgas = amount of fuel required for stoichiometric combustion/amount of gasified fuel

Here, the amount of gasified fuel means both the amount of fuel that has moved from the solid phase to the gas phase by pyrolysis, oxidation, and gasification reactions, and, the amount of gas and liquid fuel supplied to the combustible mixture. We do not consider the fuel components which are left in the solid phase. 
Figure 1. Definition of gas phase stoichiometric ratio (SRgas).

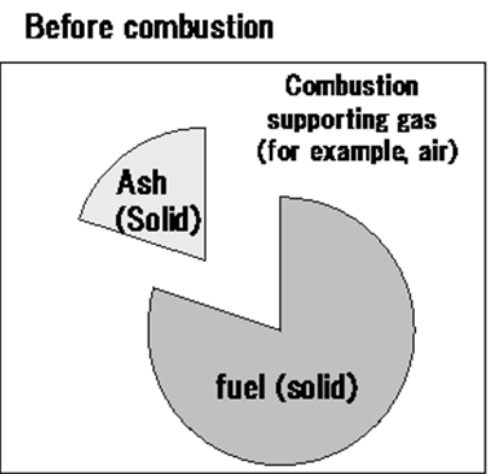

During combustion

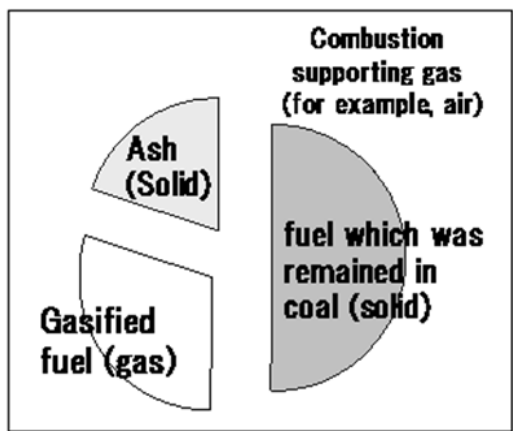

Usually, the gas phase reaction rate exceeds the solid phase reaction rate. When the gas phase reaction is the focus, sometimes the effect of the solid phase reaction can be ignored. The stoichiometric ratio is a good index which shows the difference in the burning conditions. We thought a numerical analysis might become easy when solid is removed from the burning mixture and an equivalence ratio is defined to consider the gas phase reaction.

The SRgas index can be obtained by analyzing the mass balance of $\mathrm{H}, \mathrm{C}$ and $\mathrm{O}$ in the burning gas. Sometimes, it is difficult to analyze the mass balance correctly, because the amount of water is difficult to measure. For such a situation, SRgas can be approximately by Equation (3):

$$
\text { SRgas }=\frac{X_{\mathrm{O}_{2}} / X_{\mathrm{TR} 0}}{X_{\mathrm{O}_{2} 0} / X_{\mathrm{TR} 0}-X_{\mathrm{O}_{2}} / X_{\mathrm{TR}}+0.5 X_{\mathrm{CO}} / X_{\mathrm{TR}}+0.5 X_{\mathrm{H}_{2}} / X_{\mathrm{TR}}+2 X_{\mathrm{CH}_{4}} / X_{\mathrm{TR}}}
$$

Here, $X_{\mathrm{O}_{2}}, X_{\mathrm{CO}}, X_{\mathrm{H}_{2}}$, and, $X_{\mathrm{CH}_{4}}$ are $\mathrm{O}_{2}, \mathrm{CO}, \mathrm{H}_{2}$, and $\mathrm{CH}_{4}$ mole fractions in the burning gas. $X_{\mathrm{O}_{2} 0}$ is the average mole fraction of $\mathrm{O}_{2}$ in the combustion supporting gas. $X_{\mathrm{TR}}$ is the concentration of tracer. $\mathrm{N}_{2}$, Ar and He are examples of suitable tracers. In the present study, we chose $\mathrm{N}_{2}$ as a tracer because there is hardly any change in its amount due to chemical reactions. $X_{\mathrm{TR} 0}$ is the concentration of tracer in the combustion supporting gas.

At first, combustible materials in the coal are released to the gas phase as $\mathrm{CO}$, hydrocarbons and $\mathrm{H}_{2}$. When the gas contains sufficient oxygen the $\mathrm{CO}$, hydrocarbons, and $\mathrm{H}_{2}$ are oxidized by $\mathrm{O}_{2}$ to form $\mathrm{CO}_{2}$ and $\mathrm{H}_{2} \mathrm{O}$, respectively. When the gas contains little oxygen, a part of $\mathrm{CO}$, hydrocarbon and $\mathrm{H}_{2}$ remain in the gas. The quantity of the fuel that was moved from the solid phase to gas phase could be estimated by measuring the amount of $\mathrm{O}_{2}, \mathrm{CO}$, hydrocarbon and $\mathrm{H}_{2}$ in the gas. The concentration of $\mathrm{CH}_{4}$ was mentioned specifically in Equation (3) because $\mathrm{CH}_{4}$ was the major hydrocarbon remaining in flames.

Figure 2 plots the $\mathrm{NO}_{x}$ concentration characteristics obtained for the drop-tube furnace [15]. The results were obtained for a variety of coal properties (these are summarized later in Table 1), particle diameters, burning temperatures, and compositions of combustion supporting gas. Relationships between both SRin and $\mathrm{NO}_{x}$, and SRgas and $\mathrm{NO}_{x}$ are shown in the figure. When the data were analyzed by SRin, $\mathrm{NO}_{x}$ concentration varied with experimental conditions. However, when the data were analyzed by SRgas the difference between $\mathrm{NO}_{x}$ concentrations became small and $\mathrm{NO}_{x}$ was barely influenced by the burning conditions when SRgas was less than 1.0. We judged that SRgas was a good 
index which estimated $\mathrm{NO}_{x}$ concentration in fuel-rich conditions. We further thought that the gas phase $\mathrm{NO}_{x}$ reduction was the key reaction when SRgas was smaller than 1.0; that is, the mechanism of the gas reaction did not depend so much on properties of the coal and there were many common points.

Figure 2. Relationship between gas phase stoichiometric ratio and $\mathrm{NO}_{x}$ concentration.

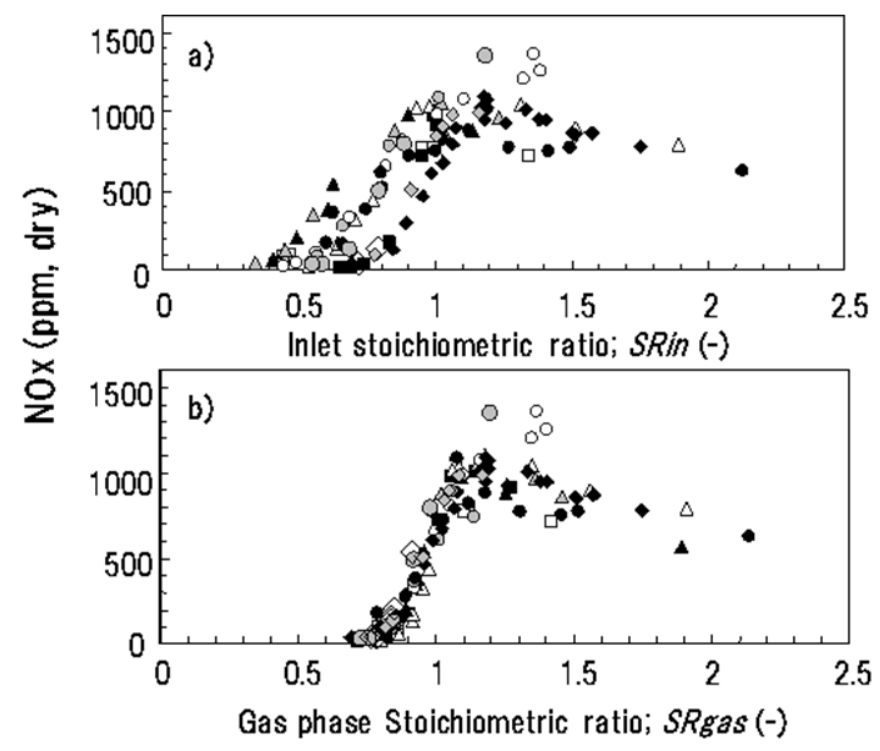

\begin{tabular}{ccccccc}
\hline Symbol & Coal & $\begin{array}{c}\text { Temp. } \\
(\mathbf{K})\end{array}$ & $\begin{array}{c}\text { Combustion } \\
\text { Supporting Gas }\end{array}$ & $\begin{array}{c}\text { Inlet } \mathbf{O}_{2} \\
(\mathbf{v o l} \%)\end{array}$ & $\begin{array}{c}\text { Diameter } \\
(\boldsymbol{\mu m})\end{array}$ & $\begin{array}{c}\mathbf{L} \\
(\mathbf{m m})\end{array}$ \\
\hline$\bullet$ & $\mathrm{A}$ & 1673 & air & 21 & 40 & 800 \\
$\bullet$ & $\mathrm{B}$ & 1573 & air & 21 & 59 & 800 \\
$\square$ & $\mathrm{C}$ & 1573 & air & 21 & 17 & 800 \\
$\Delta$ & $\mathrm{D}$ & 1573 & air & 21 & 37 & 800 \\
$\boldsymbol{\Delta}$ & $\mathrm{D}$ & 1573 & air & 21 & 37 & $200-400$ \\
$\Delta$ & $\mathrm{D}$ & 1673 & $\mathrm{CO}_{2} / \mathrm{O}_{2}$ & 21 & 37 & 800 \\
$\circ$ & $\mathrm{F}$ & 1673 & air & 21 & 45 & 800 \\
$\bullet$ & $\mathrm{F}$ & 1673 & $\mathrm{~N}_{2} / \mathrm{O}_{2}$ & 16 & 45 & 800 \\
$\bullet$ & $\mathrm{F}$ & 1673 & $\mathrm{~N}_{2} / \mathrm{O}_{2}$ & 24 & 45 & 800 \\
$\square$ & $\mathrm{J}$ & 1673 & air & 21 & 16 & 800 \\
$\diamond$ & $\mathrm{K}$ & 1873 & air & 21 & 45 & 800 \\
\hline
\end{tabular}

\subsection{Reaction Model}

Previously, we proposed a $\mathrm{NO}_{x}$ reaction model which can estimate $\mathrm{NO}_{x}$ concentrations under fuel-rich conditions [5]. The main reaction scheme is shown in Figure 3. The main feature of the model is the gas phase reaction of $\mathrm{NO}_{x}$ reduction by hydrocarbons. $\mathrm{Ox}(\mathrm{OH})$ is an important oxidative species. We thought that concentrations of hydrocarbons and $\mathrm{Ox}(\mathrm{OH})$ strongly depend on SRgas. According to the scheme, $\mathrm{NO}_{x}$ is mainly reduced by hydrocarbons to form $\mathrm{XN}\left(\mathrm{NH}_{3}, \mathrm{HCN}\right)$. Most of the $\mathrm{XN}\left(\mathrm{NH}_{3}, \mathrm{HCN}\right)$ forms $\mathrm{NO}_{x}$ again. However, the remaining $\mathrm{XN}$ reacts with $\mathrm{NO}_{x}$ to form $\mathrm{N}_{2}$. Reactions used for this study are listed in Table $1 .(\mathrm{H} / \mathrm{C})_{\mathrm{VM}}$ in Table 1 is molar ratio of $\mathrm{H}$ and $\mathrm{C}$ in volatile matter. $(\mathrm{H} / \mathrm{C})_{\text {char }}$ in Table 1 is molar ratio of $\mathrm{H}$ and $\mathrm{C}$ in char. Example of $(\mathrm{H} / \mathrm{C})_{\mathrm{VM}}$ and $(\mathrm{H} / \mathrm{C})_{\text {char values were }}$ described elsewhere [15]. 
Figure 3. Reaction model of $\mathrm{NO}_{x}$ formation and reduction.

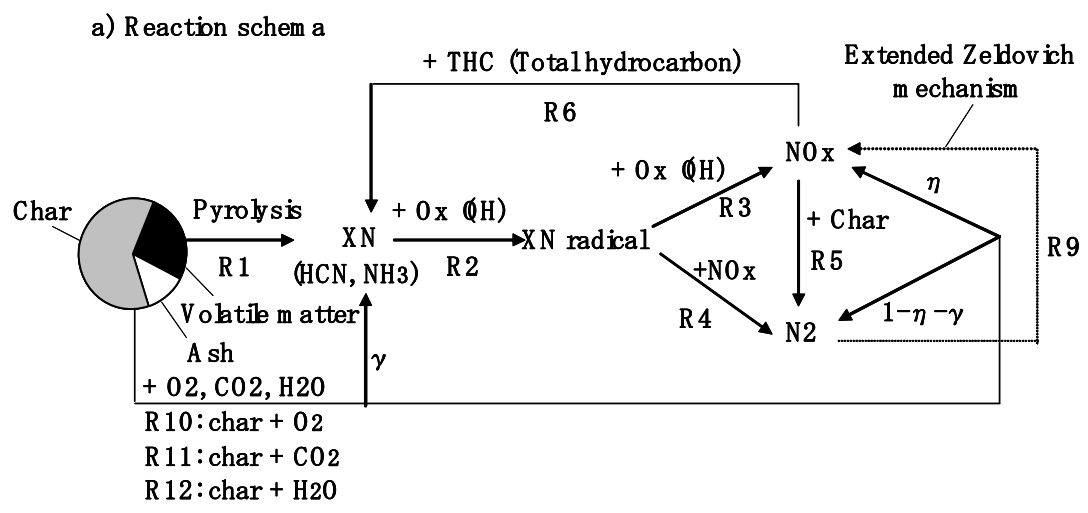

b) Form ation route of Hydrocarbon

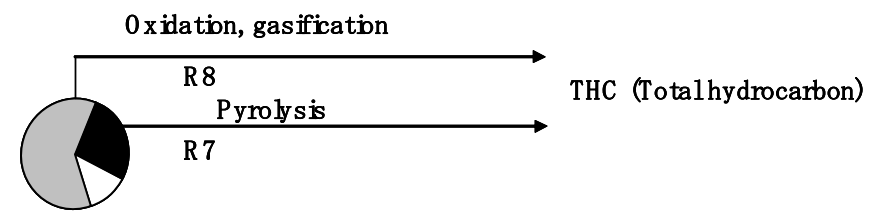

We estimated total hydrocarbons THC in the following way: hydrocarbons are mainly formed from the part of the fuel which was released from the solid phase to the gas phase by the pyrolysis, oxidation, and gasification reactions. We assumed that the amount of THC formation increases with the rates of these reactions. Hydrogen is necessary for THC formation. When the hydrogen content in a solid fuel is increased, the THC formation rate increases. It is easy to form THC in the volatile combustion region, because more hydrogen is contained in the volatile matter than in the char. Finally, we concluded that SRgas was the most important factor.

Table 1. Reactions used in this study.

\begin{tabular}{|c|c|c|}
\hline No. & Reaction & Form \\
\hline $\mathrm{R} 1$ & Pyrolysis of volatile matter & See Ref. 20 \\
\hline $\mathrm{R} 2$ & $\mathrm{XN}+\mathrm{OH} \rightarrow$ XNradical & $\mathrm{d}[\mathrm{XN}] / \mathrm{dt}=\mathrm{k}_{\mathrm{R} 2} \exp \left(-\mathrm{E}_{\mathrm{R} 2} / \mathrm{RT}\right)[\mathrm{XN}][\mathrm{OH}]$ \\
\hline R3 & $\mathrm{XNradical}+\mathrm{OH} \rightarrow \mathrm{NO}_{x}$ & $\mathrm{~d}[\mathrm{XNradical}] / \mathrm{dt}=\mathrm{k}_{\mathrm{R} 3} \exp \left(-\mathrm{E}_{\mathrm{R} 3} / \mathrm{RT}\right)[\mathrm{XNradical}][\mathrm{OH}]$ \\
\hline $\mathrm{R} 4$ & $\mathrm{XNradical}+\mathrm{NO}_{x} \rightarrow \mathrm{N}_{2}$ & $\mathrm{~d}[\mathrm{XNradical}] / \mathrm{dt}=\mathrm{k}_{\mathrm{R} 4} \exp \left(-\mathrm{E}_{\mathrm{R} 4} / \mathrm{RT}\right)[\mathrm{XNradical}]\left[\mathrm{NO}_{x}\right]$ \\
\hline R5 & $\mathrm{NO}_{x}+\mathrm{Char} \rightarrow \mathrm{N}_{2}$ & $\mathrm{~d}\left[\mathrm{NO}_{x}\right] / \mathrm{dt}=\mathrm{k}_{\mathrm{R} 5} \exp \left(-\mathrm{E}_{\mathrm{R} 5} / \mathrm{RT}\right) \mathrm{S}^{\prime}\left[\mathrm{NO}_{x}\right]^{n}$ \\
\hline R6 & $\mathrm{NO}_{x}+\mathrm{THC} \rightarrow \mathrm{N}_{2}+\mathrm{XN}$ & $\mathrm{d}\left[\mathrm{NO}_{x}\right] / \mathrm{dt}=\mathrm{k}_{\mathrm{R} 6} \exp \left(-\mathrm{E}_{\mathrm{R} 6} / \mathrm{RT}\right)\left[\mathrm{NO}_{x}\right][\mathrm{THC}]$ \\
\hline R9 & Extended Zelvovich mechnism & \\
\hline $\mathrm{R} 10$ & $\mathrm{C}+0.5 \mathrm{O}_{2} \rightarrow \mathrm{CO}$ & $\mathrm{dC} / \mathrm{dt}=\mathrm{k}_{\mathrm{R} 10} \exp \left(-\mathrm{E}_{\mathrm{R} 10} / \mathrm{RT}\right) \mathrm{S} \mathrm{P}_{\mathrm{O} 2}{ }^{n}$ \\
\hline $\mathrm{R} 11$ & $\mathrm{C}+\mathrm{CO}_{2} \rightarrow 2 \mathrm{CO}$ & $\mathrm{dC} / \mathrm{dt}=\mathrm{k}_{\mathrm{R} 11} \exp \left(-\mathrm{E}_{\mathrm{R} 11} / \mathrm{RT}\right) \mathrm{SP}_{\mathrm{CO}_{2}}{ }^{n}$ \\
\hline $\mathrm{R} 12$ & $\mathrm{C}+\mathrm{H}_{2} \mathrm{O} \rightarrow \mathrm{CO}+\mathrm{H}_{2}$ & $\mathrm{dC} / \mathrm{dt}=\mathrm{k}_{\mathrm{R} 12} \exp \left(-\mathrm{E}_{\mathrm{R} 12} / \mathrm{RT}\right) \mathrm{S} \mathrm{P}_{\mathrm{H}_{2} \mathrm{O}}{ }^{n}$ \\
\hline \multicolumn{2}{|c|}{$\begin{array}{l}\text { Estimation of Total Hydrocarbon } \\
\text { concentration }\end{array}$} & $\begin{array}{l}\mathrm{X}_{\mathrm{THC}}=\mathrm{k}_{\mathrm{THC}}\left((\mathrm{H} / \mathrm{C})_{\mathrm{VM}} \mathrm{R} 1+(\mathrm{H} / \mathrm{C})_{\text {char }}(\mathrm{R} 10+\mathrm{R} 11+\mathrm{R} 12)\right) \\
(1 / \mathrm{SRgas})^{n} \exp \left(-\mathrm{E}_{\mathrm{THC}} / \mathrm{RT}\right)\end{array}$ \\
\hline
\end{tabular}

The steady state assumption was used for reactions of XNradical. For R3 and R4, the ratio of the reaction rates (R3/R4) is important. A pyrolysis model was proposed by Yamamoto et al. [20]. The concentration of $\mathrm{OH}$ was calculated by using equilibrium concentration and gas temperature. Equation (4) proposed by Bose and Wendt [14] was used for the calculations: 


$$
[\mathrm{OH}]=1.3 \times 10^{4} \exp (13000 / \mathrm{T}) \times\left[\mathrm{OH}_{\mathrm{eq}}\right]
$$

Reaction parameters are listed in Tables 2 and 3. Table 2 shows parameters of solid phase reactions of coal K (hv-bituminous coal). These parameters vary with coal properties. Usually, the rate constants of R5, R10, R11, and R12 are decreased with fuel-ratio. The rate constant of R5 was estimated from char combustion experiments [15]. Char was burnt in $\mathrm{N}_{2}-\mathrm{O}_{2}-\mathrm{NO}$ mixtures. $\mathrm{O}_{2}$ in the surrounding gas was varied from 2 to $9 \mathrm{vol} \%$. NO in the surrounding gas was varied from 0 to $512 \mathrm{ppm}$. The rate constants were estimated by difference of the NO concentration between inlet and exit value. For some coals, the values of $k_{R 5}$ were varied with surrounding oxygen concentration. Values of $\gamma$ and $\eta$ in Figure 3 also varied with coal properties. For coal $\mathrm{K}$, $\gamma$ was 0.2 and $\eta$ was 0.07 .

Table 3 shows the gas phase reaction parameters. These parameters were the same for all coals. $\mathrm{O}_{2}$, $\mathrm{H}_{2}, \mathrm{CO}$ and $\mathrm{CO}_{2}$ concentration in the drop-tube furnace were measured under various temperatures and stoichiometric ratios. Concentrations of these species could be similar by equilibrium values.

Table 2. Parameters of solid phase reactions.

\begin{tabular}{cccc}
\hline Reaction & $\mathbf{k}$ & $\mathbf{E}$ & $\mathbf{n}$ \\
\hline $\mathrm{R} 5\left(\mathrm{~mol}-\mathrm{NO} / \mathrm{m}^{3}\right.$-total gas s) & $\mathrm{k}_{\mathrm{R} 5}=0.865+10.8 \mathrm{X}_{\mathrm{O}_{2}}\left(\left(\mathrm{~m}^{3} / \mathrm{mol}\right)^{0.9} \mathrm{~m} \mathrm{~s}^{-1}\right)$ & $28(\mathrm{~kJ} / \mathrm{mol})$ & 0.9 \\
$\mathrm{R} 10(\mathrm{~kg}$-carbon$/ \mathrm{kg}$-total gas s) & $7.99 \times 10^{-4}\left(\mathrm{~kg} / \mathrm{m}^{2} \mathrm{~Pa} \mathrm{~s}\right)$ & $66(\mathrm{~kJ} / \mathrm{mol})$ & 1 \\
$\mathrm{R} 11$ (kg-carbon$/ \mathrm{kg}$-total gas s) & $1.46 \times 10^{-3}\left(\mathrm{~kg} / \mathrm{m}^{2} \mathrm{~Pa} \mathrm{~s}\right)$ & $154(\mathrm{~kJ} / \mathrm{mol})$ & 1 \\
$\mathrm{R} 12(\mathrm{~kg}$-carbon$/ \mathrm{kg}$-total gas s) & $1.46 \times 10^{-2}\left(\mathrm{~kg} / \mathrm{m}^{2} \mathrm{~Pa} \mathrm{~s}\right)$ & $154(\mathrm{~kJ} / \mathrm{mol})$ & 1 \\
$\mathrm{X}_{\mathrm{THC}}\left(\right.$ mole fraction, as $\left.\mathrm{CH}_{4}\right)$ & $3.15 \times 10^{-9}(\mathrm{~kg}$-total gas s$/ \mathrm{kg}$-carbon $)$ & $-195(\mathrm{~kJ} / \mathrm{mol})$ & 13 \\
\hline
\end{tabular}

Table 3. Parameters of gas phase reactions.

\begin{tabular}{ccc}
\hline Reaction & $\mathbf{k}$ & $\mathbf{E}$ \\
\hline $\mathrm{R} 2\left(\mathrm{~mol} / \mathrm{m}^{3} \mathrm{~s}\right)$ & $4.6899 \times 10^{6}\left(\mathrm{~m}^{3} / \mathrm{mol} \mathrm{s}\right)$ & $43.2(\mathrm{~kJ} / \mathrm{mol})$ \\
$\mathrm{R} 3\left(\mathrm{~mol} / \mathrm{m}^{3} \mathrm{~s}\right)$ & $5.35 \times 10^{10}\left(\mathrm{~m}^{3} / \mathrm{mol} \mathrm{s}\right)$ & $168(\mathrm{~kJ} / \mathrm{mol})$ \\
$\mathrm{R} 4\left(\mathrm{~mol} / \mathrm{m}^{3} \mathrm{~s}\right)$ & $1.52 \times 10^{12}\left(\mathrm{~m}^{3} / \mathrm{mol} \mathrm{s}\right)$ & $251(\mathrm{~kJ} / \mathrm{mol})$ \\
$\mathrm{R} 5\left(\mathrm{~mol} / \mathrm{m}^{3} \mathrm{~s}\right)$ & $1.64 \times 10^{15}\left(\mathrm{~m}^{3} / \mathrm{mol} \mathrm{s}\right)$ & $372(\mathrm{~kJ} / \mathrm{mol})$ \\
\hline
\end{tabular}

\subsection{Calculated Results}

Figures 4, 5 and 6 show verifications of the calculation model using the experimental results obtained with the drop-tube furnace. Figure 4 shows the effect of coal properties (see Table 4 below) and burning temperature on $\mathrm{NO}_{x}$ concentration. We checked the results for both the relationships between SRin and $\mathrm{NO}_{x}$, and SRgas and $\mathrm{NO}_{x}$. The calculated results reproduced both characteristics. When SRgas was less than 1.0, $\mathrm{NO}_{x}$ was influenced by SRgas, while it was hardly influenced at all by the other experimental conditions.

We checked the model for around 200 other experimental conditions. We changed oxygen and $\mathrm{NO}_{x}$ concentrations in the combustion supporting gas, particle diameters, and burning times $(\mathrm{L}=400-800 \mathrm{~mm})$. The results are shown in Figure 5. The difference between experimental and calculated results was approximately $20 \%$. When particle size was very large, calculation precision decreased. The calculation did not predict the value of SRgas well, because the calculation error of the coal burnout became large. At first, it is important to predict the value of SRgas well, for predicting $\mathrm{NO}_{x}$ concentration well. 
Figure 4. Effect of coal properties and burning temperature on $\mathrm{NO}_{x}$ concentration, symbols are experimental results and lines are calculated results.

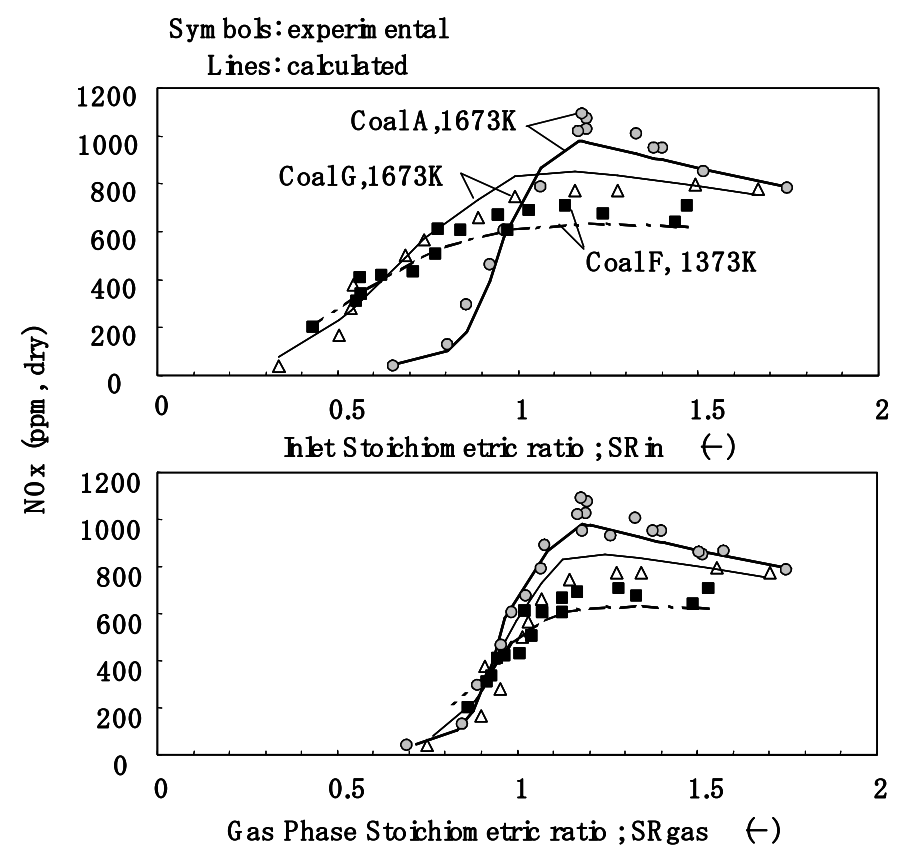

Figure 5. Comparison between measured (symbols) and calculated (line) $\mathrm{NO}_{x}$ concentrations.

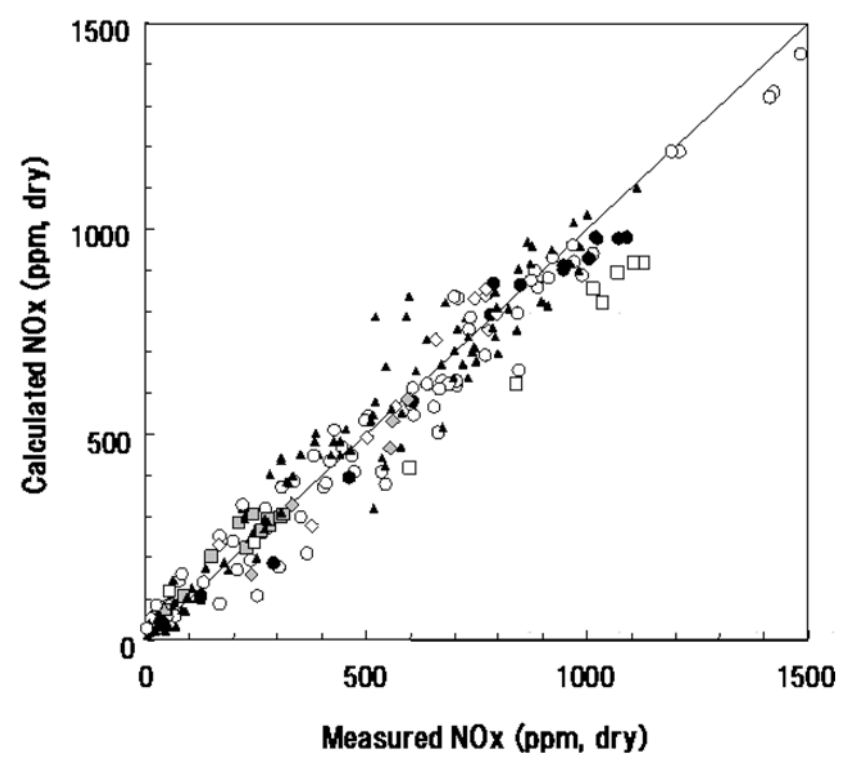

\begin{tabular}{ccccccc}
\hline Symbol & Coal & $\begin{array}{c}\text { Temp. } \\
(\mathbf{K})\end{array}$ & $\begin{array}{c}\text { Inlet } \mathbf{O}_{\mathbf{2}} \\
(\mathbf{v o l} \%)\end{array}$ & $\begin{array}{c}\text { Inlet NO } \\
(\mathbf{p p m})\end{array}$ & $\begin{array}{c}\text { Diameter } \\
(\boldsymbol{\mu m})\end{array}$ & $\begin{array}{c}\mathbf{L} \\
(\mathbf{m m})\end{array}$ \\
\hline$\bullet$ & $\mathrm{A}$ & 1673 & 21 & 0 & 40 & 800 \\
$\boldsymbol{\Delta}$ & $\mathrm{B}$ & $1173-1773$ & 21 & 0 & $23-155$ & $400-800$ \\
$\square$ & $\mathrm{E}$ & 1673 & 21 & 0 & 22 & 800 \\
$\circ$ & $\mathrm{F}$ & $1173-1673$ & $16-24$ & $0-1000$ & $14-45$ & 800 \\
$\diamond$ & $\mathrm{G}$ & 1673 & 21 & 0 & 40 & 800 \\
$\diamond$ & $\mathrm{H}$ & 1673 & 21 & 0 & 33 & 800 \\
$\square$ & $\mathrm{I}$ & 1673 & 21 & 0 & 35 & 800 \\
\hline
\end{tabular}


Staged combustion properties were also verified for coal K. Typical results are shown in Figure 6. Structures of the drop-tube furnace for staged combustion are shown later (Figure 16). Burning temperatures of these experiments were higher than those shown in Figure 4 and $5 . \mathrm{NO}_{x}$ concentration and carbon in ash were measured at the furnace exit. The proposed model was also verified for staged combustion conditions.

Figure 6. Staged combustion properties of coal K. Exit stoichiometric ratio was 1.2. Burning temperature was $1873 \mathrm{~K}$ for the burner zone and $1673 \mathrm{~K}$ for the staged combustion zone. Residence time was around $1.4 \mathrm{~s}$ for the burner zone and around $1.0 \mathrm{~s}$ for the staged combustion zone. Symbols are experimental and lines are calculated results.
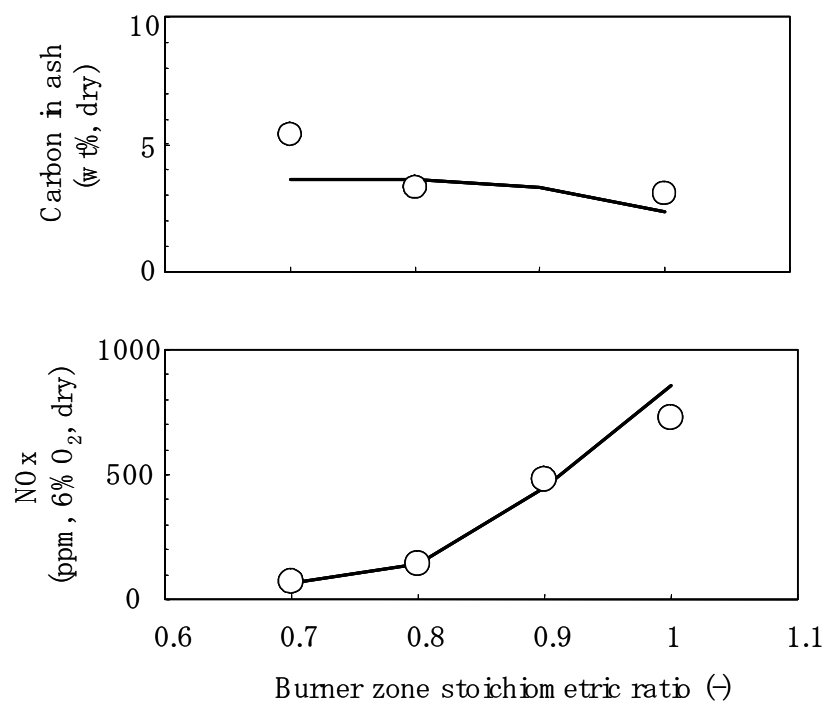

\subsection{Application of SRgas to Low-NO ${ }_{x}$-Combustion Technology Development in the Air Combustion Experiment}

Structures of the laboratory scale furnace for the air combustion experiment are shown in Figure 7 [1]. The furnace was the down flow type combustor, in which pulverized coal particles and air were supplied from the upper part of the apparatus. The combustion air was divided into the primary (1ry), secondary (2ry) and ternary (3ry) air. Coal feed rate was approximately $25 \mathrm{~kg} / \mathrm{h}$. Pulverized coals were supplied through the primary air nozzle. Burner Nozzles A and B structures are shown in Figure 8. The structure of the third Nozzle $C$ was the same as that of Nozzle B, but the angles of their swirler vanes were different. The nozzles used the swirler vane to form a swirled flow, and plate-like members to obtain a straight flow. The effects of the swirler vane and the plate-like members were described previously [21]. In the present study, we tested $\mathrm{NO}_{x}$ emission by varying the diameter of the primary nozzle, the size of the swirler vane and the plate-like members, and the angle of the swirler vane.

Figure 9 shows the relationship between burner stoichiometric ratio and $\mathrm{NO}_{x}$ emission obtained for the three nozzles. Coal $\mathrm{E}$ (see Table 1) was used for these experiments. $\mathrm{NO}_{x}$ emission using Nozzle $\mathrm{B}$ was the lowest, followed by Nozzle A and Nozzle C. 
Figure 7. Schematic diagram of the laboratory scale furnace (unit: $\mathrm{mm}$ ).

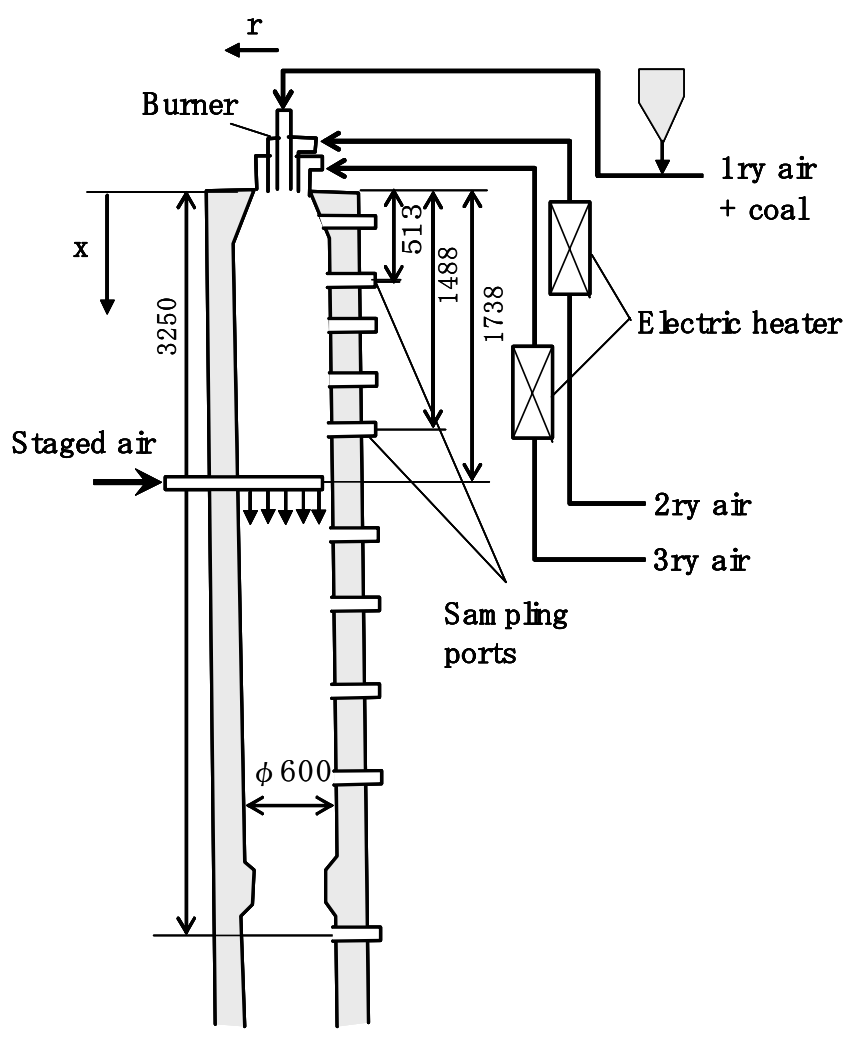

Figure 8. Structure of burner and nozzles (unit: mm).

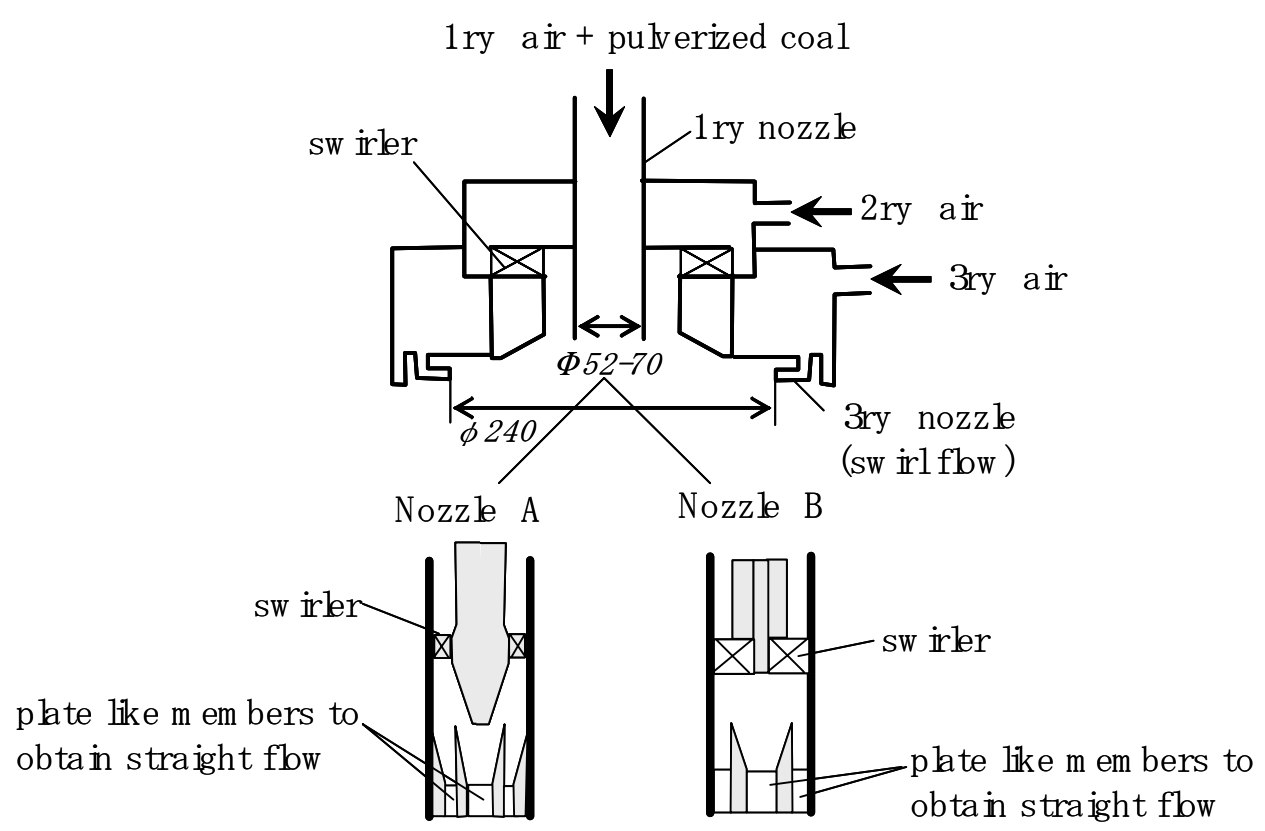


Figure 9. Comparison of $\mathrm{NO}_{x}$ emissions for three burner structures at different stoichiometric ratios. Exit stoichiometric ratio was 1.15 for all experiments (exit $\mathrm{O}_{2}$ was 2.7 vol\%, dry).

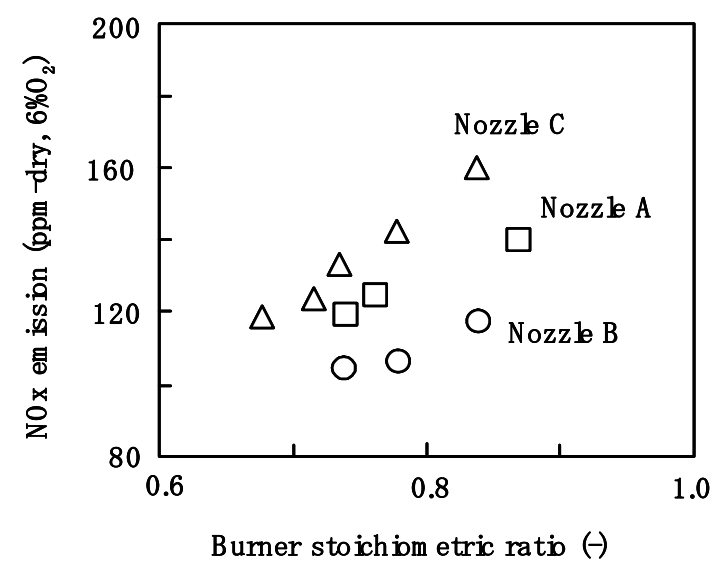

We measured local SRgas distributions in the flames and the results are shown in Figure 10. Local SRgas distributions were measured at two different axial positions. One was obtained in the burner neighborhood $(x=513 \mathrm{~mm})$ and the other was obtained just before the staged air nozzle $(x=1488 \mathrm{~mm})$. SRgas had the minimum value at the central axis, and it increased near the side wall of the furnace. Then we investigated the effect of nozzle structure on SRgas. When we used the low- $\mathrm{NO}_{x}$ type Nozzle B, the value of SRgas was easily decreased. The same characteristics were observed at both $X=513 \mathrm{~mm}$ and $X=1488 \mathrm{~mm}$. SRgas was also a good index for investigating the reason why $\mathrm{NO}_{x}$ emissions were reduced. When the $\mathrm{NO}_{x}$ concentration was compared for the same axial position, the $\mathrm{NO}_{x}$ concentration was strongly influenced by SRgas, but hardly influenced by the nozzle structure. The key to low $\mathrm{NO}_{x}$ combustion technology development is reducing the value of SRgas in the burner zone as much as possible.

Figure 10. Distribution of gas phase stoichiometric ratio for the laboratory scale furnace.

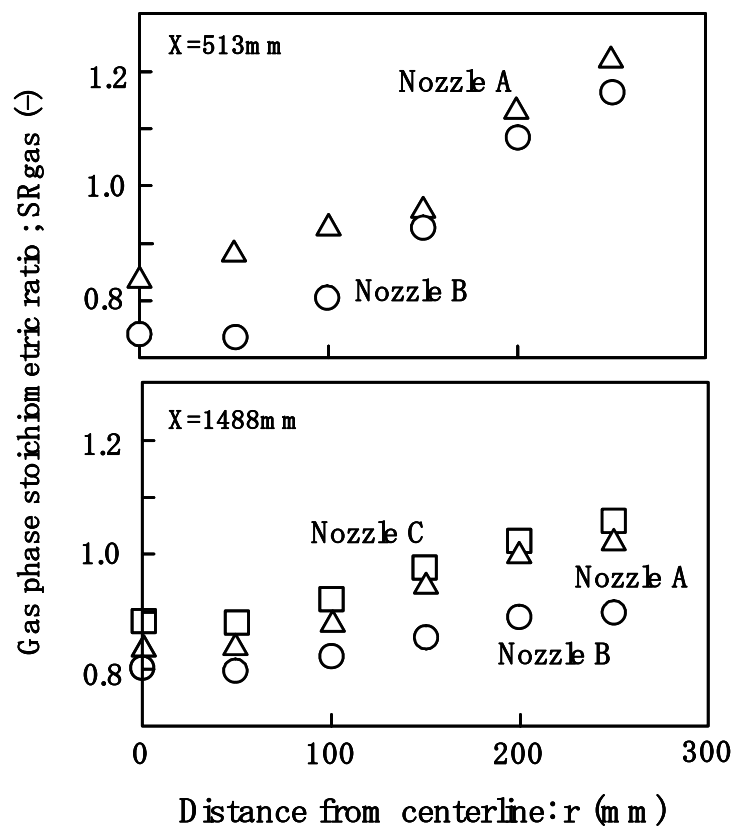


The relationship between SRgas and $\mathrm{NO}_{x}$ concentration obtained in the drop-tube furnace is shown in Figure 11. We compared $\mathrm{NO}_{x}$ concentration obtained just before the staged air nozzle $(x=1488 \mathrm{~mm})$. When SRgas was less than $0.9, \mathrm{NO}_{x}$ concentrations obtained by the laboratory scale furnace and drop-tube furnace were almost the same. $\mathrm{NO}_{x}$ concentration was made stable by SRgas. $\mathrm{NO}_{x}$ emission was strongly influenced by how much the SRgas value could be reduced just before staged air injection. The $\mathrm{NO}_{x}$ concentration in the vicinity of the burner $(x=513 \mathrm{~mm})$ was higher than that obtained downstream $(x=1488 \mathrm{~mm})$. The SRgas was a good index to consider $\mathrm{NO}_{x}$ performance, but, in the burner neighborhood, it did not predict the actual value. We thought that one of the reasons was the concentration fluctuation. Flow turbulence could be strong in the burner neighborhood. This might cause concentration fluctuation. In the burner neighborhood, both reductive gas $(S R g a s<1.0)$ and oxidative gas (SRgas $>1.0$ ) conditions were observed at the same position. $\mathrm{NO}_{x}$ in oxidative gas was high, so that $\mathrm{NO}_{x}$ in the burner neighborhood became high, even if SRgas was low.

Figure 11. Relationship between gas phase stoichiometric ratio and $\mathrm{NO}_{x}$ concentration for the laboratory scale furnace.

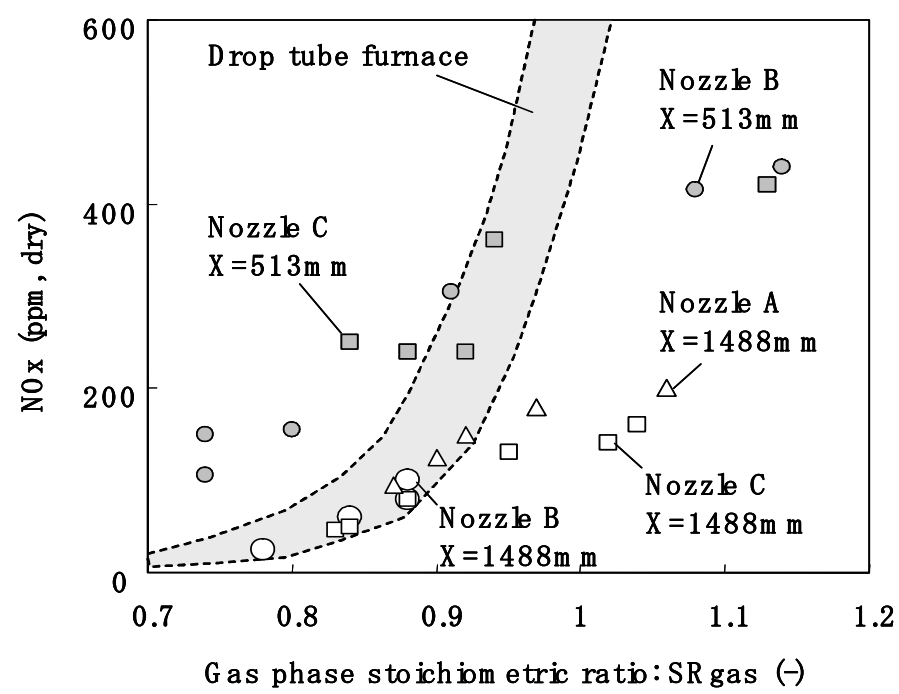

We examined why $\mathrm{NO}_{x}$ emissions varied with nozzle structures. Figure 12 shows differences in flow and coal concentration distributions near the burner exit between Nozzles A, B and C. Swirl flow was formed inside the nozzle. The local coal concentration of nozzle circumference rose by the centrifugal force of the swirl flow. The plate-like members installed at the nozzle exit changed swirl flow into straight flows. The resulting phenomenon was that local coal concentrations rose as the nozzle circumference side was maintained. The coals ignited from the circumference side of the nozzle. When the coal concentration rose, ignition was accelerated, then, the flame temperature rose rapidly. Oxidation and gasification reactions were accelerated because of high flame temperature, then, coal burnout in the burner zone easily increased. SRgas value was easy to decrease, so $\mathrm{NO}_{x}$ concentration decreased.

The swirl strength of Nozzle B was larger than that of Nozzle A. Consequently the local coal concentration in the nozzle circumference of Nozzle B was larger than that of Nozzle A, and coal ignition in Nozzle B became easy. 
The swirl strength of Nozzle $\mathrm{C}$ was very large, however, swirl ingredients were left at the nozzle exit. The coal particles which gathered in the nozzle circumference spread more on the circumference side. For Nozzle C, the local coal concentration at the nozzle exit could not kept high. Coal ignition was not accelerated.

Figure 12. Images of flow and coal concentration distributions near the burner exit for Nozzles A, B and C.
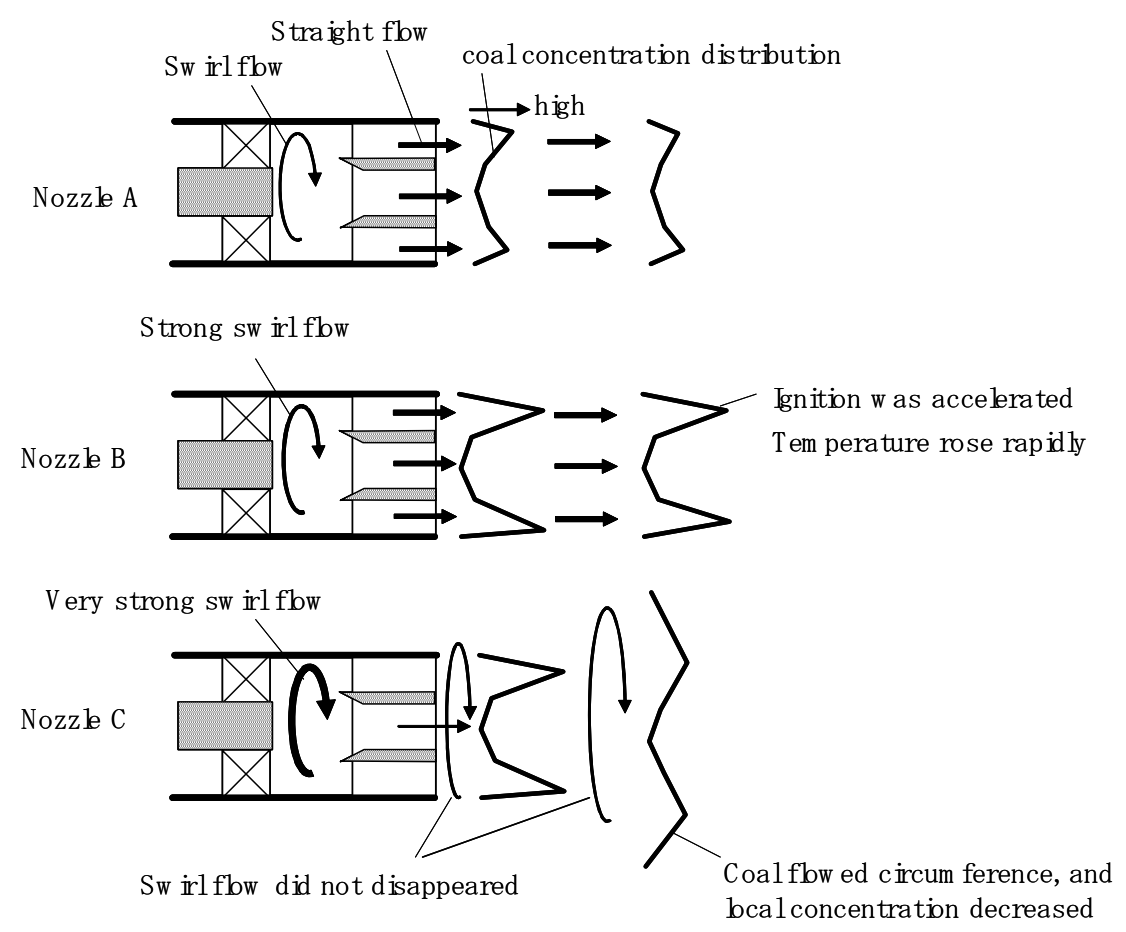

\subsection{Application of SRgas to Low-NO $\mathrm{N}_{x}$-Combustion Technology Development in the Oxyfuel Combustion Calculation}

We applied the model to the oxyfuel combustion calculation for a boiler. Two kinds of $\mathrm{NO}_{x}$ are formed from pulverized coal combustion, thermal $\mathrm{NO}_{x}$ and fuel $\mathrm{NO}_{x}$. The SRgas mainly affects prediction of the fuel $\mathrm{NO}_{x}$ as most of the $\mathrm{NO}_{x}$ generated in oxyfuel combustion is fuel $\mathrm{NO}_{x}$, because the combustion supporting gas only contains a little nitrogen.

We calculated $\mathrm{NO}_{x}$ emissions for a pulverized coal firing boiler. We used a boiler of average size and structure based on publicly available information [22-26] about recent pulverized coal firing power plants. The electric output was around $1000 \mathrm{MW}$. Figure 13 shows calculation conditions and example results for the calculated concentration distributions of $\mathrm{O}_{2}$ and $\mathrm{NO}_{x}$, and gas temperature distribution. The calculation method was shown previously $[7,8] . \mathrm{NO}_{x}$ near the burner neighborhood was high, where oxygen concentration and SRgas were high. The oxygen concentration and SRgas decreased at the center of the furnace where $\mathrm{NO}_{x}$ was reduced and the $\mathrm{NO}_{x}$ concentration increased a little by mixing with staged air.

The variations in SRgas in the furnace are shown in Figure 14. The SRgas distributions are expressed as an average for a horizontal section of the furnace. The SRgas depended on the burner arrangement. We compared the SRgas values just before mixing with staged air. The SRgas of Case 2 
was lower than that of Case $1 . \mathrm{NO}_{x}$ emissions, $\mathrm{O}_{2}$ concentration, and unburned carbon in fly-ash at the exit of the furnace are shown in the figure. Oxygen concentration and unburned carbon in fly-ash were equal. However, the $\mathrm{NO}_{x}$ emission of Case 2 was lower than that of Case 1. The SRgas became lower just before mixing with staged air, and $\mathrm{NO}_{x}$ emission became lower. The results were the same as obtained from the experiments. In development of the low $\mathrm{NO}_{x}$ combustion technology, the SRgas was a good index for investigating the mechanism of $\mathrm{NO}_{x}$ reduction.

Figure 13. Numerical calculation for oxyfuel combustion.

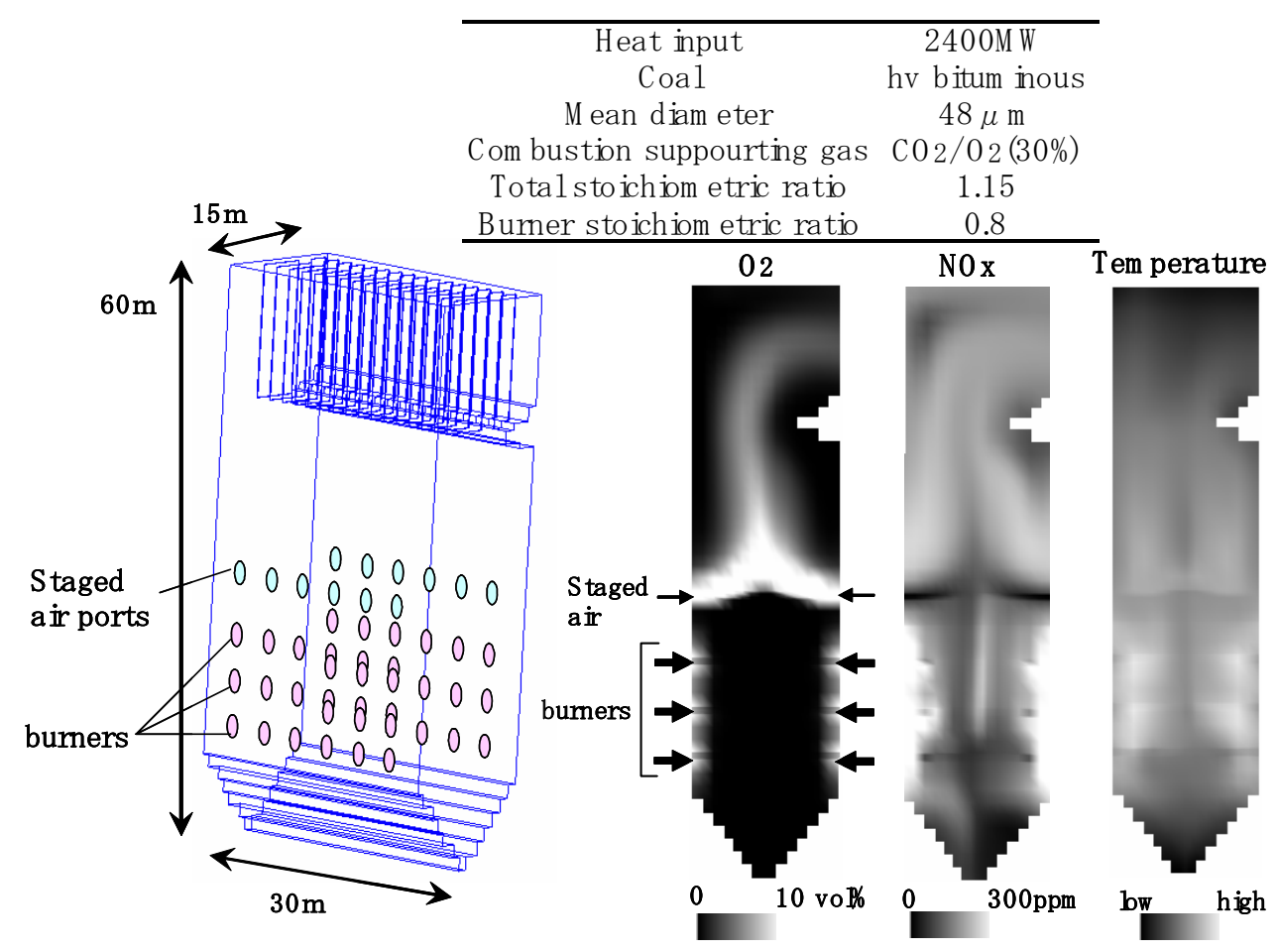

Figure 14. Distribution of calculated gas phase stoichiometric ratio.

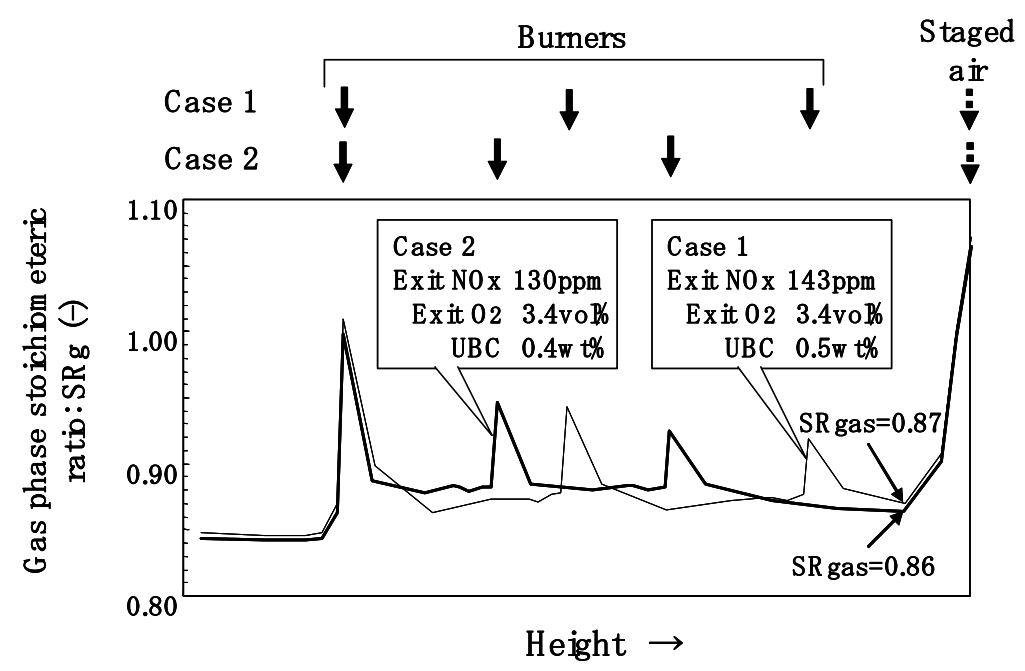

The burner arrangements for CASE 1 and CASE 2 are described in Figure 15. Areas shown by dotted lines represent the main combustion region. Much of the supplied coal burned in this area. Much of the supplied heat was released in the area too. Total heat input of CASE 1 and CASE 2 were 
the same, however, the main combustion region of CASE 1 was larger than that of CASE 2. Flame temperature in the main combustion region of CASE 2 was easy to increase, because heat was released in a small area. Oxidation and gasification reactions were accelerated for CASE 2, so that the corresponding SRgas value was easy to decrease.

Figure 15. Arrangement of Burners for CASE 1 and CASE 2.

CASE 1

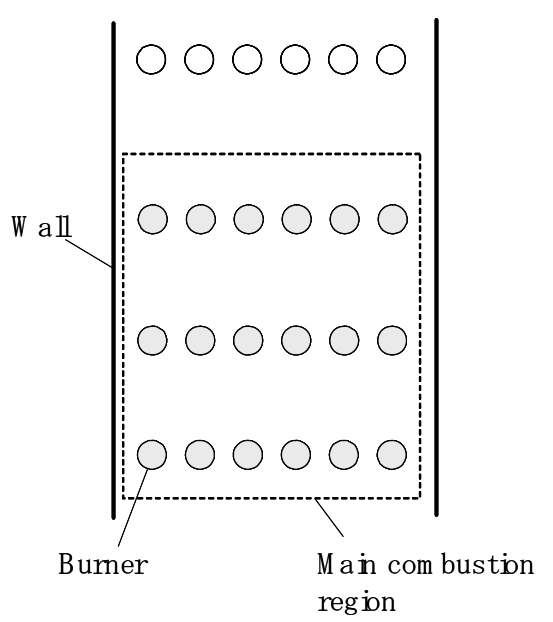

CASE 2

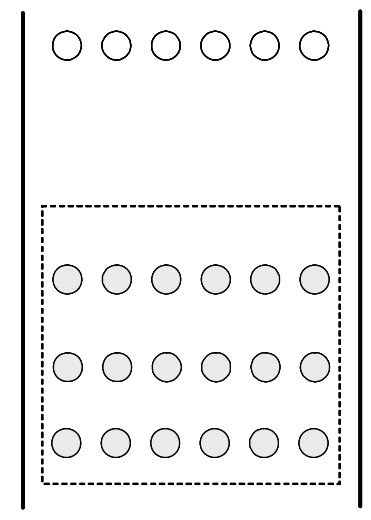

\section{Experimental Section}

The drop-tube furnace we used was described elsewhere [15]. The reaction zone (maximum length, $1200 \mathrm{~mm}$ ) was made of an alumina tube which had an inner diameter of $50 \mathrm{~mm}$. The heating rate was $15,000 \mathrm{~K} / \mathrm{s}$. The flow rate of combustion supporting gas $\left(\mathrm{O}_{2} / \mathrm{N}_{2}\right)$ was $0.96 \mathrm{~m}^{3} \mathrm{~N} / \mathrm{h}$ and the supply rated of pulverized coals was $0.02-0.5 \mathrm{~kg} / \mathrm{h}$. A nozzle supplied the pulverized coals and combustion supporting gas to the furnace. The burning temperature (measured as the wall temperature) was 1173-1773 K. We changed the length $(L)$ from the nozzle to a sampling port between 200 , 400, and $800 \mathrm{~mm}$. The reaction time was changed between approximately $0.25-1.0 \mathrm{~s}$. Gas composition and ash content in unburned char were measured.

Staged combustion properties were also examined. The structure of the drop-tube furnace for staged combustion is shown in Figure 16. Two high-temperature electric furnaces were connected in series. The basic structure of the each drop-tube furnace was the same as described previously [15]. The maximum temperature was risen to $2100 \mathrm{~K}$ by using a carbon electric heater. Gasification reaction rates have been studied using a pressurized high-temperature drop-tube furnace [27]. We modified that the furnace to allow use at atmospheric pressure, and we used this design for the basic construction of our two electric furnaces. Coal and air (air for the burner zone) were supplied from the upper part of the electric furnace in the upper section. Coal was burnt under fuel-rich conditions in the upper electric furnace. Staged air was supplied at the connection of the two electric furnaces. The total amount of air (air for burner zone + staged air) was $0.96 \mathrm{~m}^{3} \mathrm{~N} / \mathrm{h}$.

Analyses of eleven coal samples are listed in Table 4. Five types were studied: sub-bituminous, hvbituminous, mv-bituminous, and anthracite, and petroleum coke. 
Figure 16. Structure of the drop-tube furnace for staged combustion.

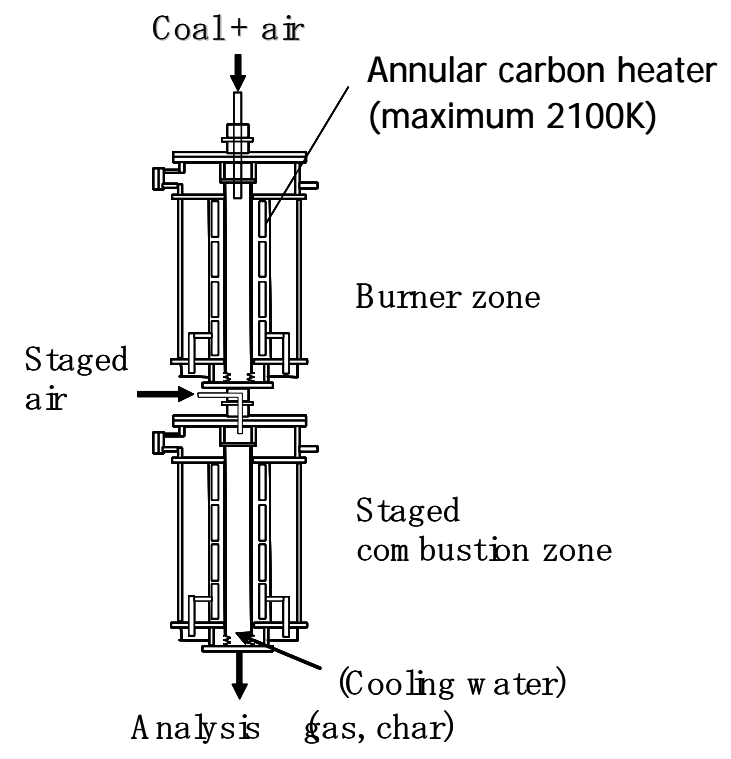

Table 4. Analysis of studied coals.

\begin{tabular}{|c|c|c|c|c|c|c|c|c|c|c|c|}
\hline \multirow[t]{2}{*}{ Name } & \multirow{2}{*}{ Coal } & \multirow{2}{*}{ Area } & VM & Ash & \multirow{2}{*}{$\begin{array}{l}\text { Fuel } \\
\text { Ratio }\end{array}$} & $\mathbf{C}$ & $\mathbf{H}$ & $\mathbf{N}$ & $\mathbf{O}$ & $\mathbf{S}$ & \multirow{2}{*}{$\begin{array}{c}\text { Mean } \\
\text { Diameter } \\
(\mu \mathrm{m})\end{array}$} \\
\hline & & & \multicolumn{2}{|c|}{ (wt\%, dry) } & & \multicolumn{5}{|c|}{ (wt\%, dry, ash-free) } & \\
\hline A & sub-bituminous & Asia & 41.6 & 15.7 & 1.0 & 74.2 & 6.2 & 1.8 & 17.1 & 0.8 & 40 \\
\hline B & sub-bituminous & Noth America & 43.6 & 6.2 & 1.2 & 69.1 & 5.4 & 1.1 & 23.8 & 0.6 & $23,59,155$ \\
\hline $\mathrm{C}$ & hv-bituminous & Noth America & 36.3 & 18.7 & 1.2 & 76.7 & 5.5 & 1.6 & 12.6 & 3.6 & 17 \\
\hline $\mathrm{D}$ & hv-bituminous & Oceania & 31.1 & 14.9 & 1.7 & 81.1 & 5.8 & 1.8 & 10.7 & 0.7 & 37 \\
\hline $\mathrm{E}$ & hv-bituminous & Oceania & 27.6 & 10.2 & 2.3 & 81.5 & 4.6 & 1.8 & 11.7 & 0.5 & 22 \\
\hline $\mathrm{F}$ & hv-bituminous & Oceania & 26.3 & 12.8 & 2.3 & 84.9 & 5.5 & 1.9 & 7.2 & 0.5 & 14,45 \\
\hline G & mv-bituminous & Oceania & 20.6 & 8.5 & 3.4 & 87.6 & 4.7 & 2.1 & 4.8 & 0.8 & 40 \\
\hline $\mathrm{H}$ & petroleum coke & Noth America & 11.8 & 2.4 & 7.3 & 88.7 & 3.3 & 1.5 & 1.3 & 5.4 & 33 \\
\hline I & anthracite & Asia & 8.9 & 13.3 & 8.7 & 92.3 & 1.7 & 0.5 & 5.2 & 0.3 & 35 \\
\hline $\mathrm{J}$ & anthracite & Asia & 7.6 & 25.3 & 8.8 & 90.7 & 3.5 & 1.4 & 3.5 & 1 & 16 \\
\hline $\mathrm{K}$ & hv-bituminous & Oceania & 32.5 & 14.3 & 1.6 & 83.4 & 5.4 & 1.9 & 8.8 & 0.5 & 45 \\
\hline
\end{tabular}

\section{Conclusions}

We applied a gas phase stoichiometric ratio index (SRgas) to predict $\mathrm{NO}_{x}$ concentrations, to develop the $\mathrm{NO}_{x}$ reaction model and a new low- $\mathrm{NO}_{x}$-combustion technology.

(1) Gas phase stoichiometric ratio (SRgas) was defined as:

SRgas = amount of fuel required for stoichiometric combustion/amount of gasified fuel where the amount of gasified fuel was defined as the amount of fuel which had been released to the gas phase by pyrolysis, oxidation and gasification reactions. SRgas was determined to be a good index to consider the gas phase reaction mechanism in fuel-rich pulverized coal flames.

(2) We applied the SRgas index to develop a $\mathrm{NO}_{x}$ reaction model. The key feature was that the concentration of hydrocarbons was estimated as a function of SRgas. Calculated $\mathrm{NO}_{x}$ 
characteristics reproduced the experimental results obtained from a drop-tube furnace. The model was verified for various coals, particle diameters, reaction times and initial oxygen concentrations.

(3) We applied SRgas to develop a low- $\mathrm{NO}_{x}$-combustion system. When using staged combustion, it was important to reduce the SRgas value as much as possible, just before mixing with staged air. When we adopted the burner structure and the placement at which SRgas became the lowest, the $\mathrm{NO}_{x}$ emission of the furnace became the lowest as well.

\section{References}

1. Azuhata, A.; Narato, K.; Kobayashi, H.; Arashi, N.; Morita, S.; Masai, T. A study of gas composition profiles for low $\mathrm{NO}_{x}$ pulverized coal combustion and burner scale-up. Proc. Combust. Inst. 1986, 21, 1199-1206.

2. Förtsch, D.; Kluger, F.; Schnell, U.; Spliethoff, H.; Hein, K.R.G. A kinetic model for the prediction of NO emission from staged combustion of pulverized coal. Proc. Combust. Inst. 1998, 27, 3037-3044.

3. Cancès, J.; Commandrè, J.M.; Salvador, S.; Dagaut, P. NO reduction capacity of four major solid fuels in reburning conditions-Experiments and modeling. Fuel 2008, 87, 274-289.

4. Tsumura, T.; Morita, S.; Kiyama, K.; Kobayashi, H.; Yoshizako, H. Development of Extremely Low $\mathrm{NO}_{x}$ Pulverized Coal Burners by Using the Concept of "In-Flame $\mathrm{NO}_{x}$ Reduction". In Proceedings of JSME-ASME International Conference on Power Engineering-93, Tokyo, Japan, 12-16 September 1993; Volume 2, pp. 325-330.

5. Taniguchi, M.; Kamikawa, K.; Okazaki, T.; Yamamoto, K.; Orita, H. A role of hydrocarbon reaction for $\mathrm{NO}_{x}$ formation and reduction in fuel-rich pulverized coal combustion. Combust. Flame 2010, 157, 1456-1466.

6. Williams, A.; Pourkashanian, M.; Bysh, P.; Norman, J. Modeling of coal combustion in low-NO $\mathrm{NO}_{x}$ p.f. flames. Fuel 1994, 73, 1006-1019.

7. Yamamoto, K., Fukuchi, T.; Chaki, M.; Shimogori, Y.; Matsuda, J. Development of Computer Program for Combustion Analysis in Pulverized Coal Fired Boilers. Hitachi Rev. 2000, 49, 4976-4980.

8. Yamamoto, K.; Taniguchi, M.; Kobayashi, H.; Sakata, T.; Kudo, K. Validation of coal combustion model by using experimental data of utility boilers. JSME Int. J. Ser. B 2005, 48, 571-578.

9. Le Bris, T.; Cadavid, F.; Caillat, S.; Pietrzyk, S.; Blondin, B.; Baudoin, B. Coal combustion modeling of large power plant, for $\mathrm{NO}_{x}$ abatement. Fuel 2007, 86, 2213-2220.

10. Man, C.K.; Gibbins, J.R.; Wikamp, J.G.; Zhang, J.; Schonenbeck, C.; Gadiou, R.; Schwartz. D. Coal characterization for $\mathrm{NO}_{x}$ prediction in air-staged combustion of pulverized coals. Fuel 2005, 85, 2190-2195.

11. Díez, L.I.; Cortés, C.; Pallarés, J. Numerical investigation of $\mathrm{NO}_{x}$ emission from a tangentiallyfired utility boiler under conventional and overfire air operation. Fuel 2008, 87, 1259-1269.

12. Kambara, S.; Takarada, T.; Toyoshima, M.; Kato, K. Relation between functional forms of coal nitrogen and $\mathrm{NO}_{x}$ emissions from pulverized coal combustion. Fuel 1995, 74, 1247-1253. 
13. Niksa, S.; Liu, G.S. Incorporating detailed reaction mechanisms into simulations of coal-nitrogen conversion in p.f. flames. Fuel 2002, 81, 2371-2385.

14. Bose, A.C.; Wendt, J.O.L. Pulverized coal combustion: fuel nitrogen mechanisms in the rich post-flame. Proc. Combust. Inst. 1998, 22, 1127-1134.

15. Taniguchi, M.; Yamamoto, K.; Kobayashi, H.; Kiyama, K. A reduced $\mathrm{NO}_{x}$ reaction model for pulverized coal combustion under fuel-rich conditions. Fuel 2002, 81, 363-371.

16. Chambrion, P.; Kyotani, T.; Tomita, A. C-NO reaction in the presence of $\mathrm{O}_{2}$. Proc. Combust. Inst. 1998, 27, 3053-3059.

17. Aarna, I.; Suuberg, E.M. A study of the reaction order of the NO-carbon gasification reaction. Proc. Combust. Inst. 1998, 27, 3061-3068.

18. Guo, F.; Hecker, W.C. Kinetics of $\mathrm{NO}_{x}$ reduction by char: Effect of coal rank. Proc. Combust. Inst. 1998, 27, 3085-3092.

19. Schöonenbeck, C.; Gadiou, R.; Schwartz, D. A kinetic study of the high temperature NO-char reaction. Fuel 2004, 83, 443-450.

20. Yamamoto, K.; Murota, T.; Okazaki, T.; Taniguchi, M. Large eddy simulation of a pulverized coal jet flame ignited by a preheated gas flow. Proc. Combust. Inst. 2010, 33, 1771-1778.

21. Narato, K.; Kobayashi, H.; Taniguchi, M.; Kouno, T.; Okazakki, H.; Ito, K.; Morita, S.; Baba, A. Pulverized coal combustion burner. U.S. Patent 5685242, 11 November 1997.

22. Richardson M.; Shimogori, Y.; Kidera, Y. Supercritical Boiler Technology Matures. Available online: http://www.hitachipowersystems.us/supportingdocs/forbus/hpsa/technical_papers/CG2004. pdf (accessed on 14 March 2011).

23. Irie, K.; Suganuma, H.; Momoo, T., Komada, S.; Kojima, S. Commencement of the commercial operation of world's top performing 900MW unit "Maizuru No.1 thermal power station of the kansai electric power Co. Inc.”. Mitsubishi Juko Giho 2004, 41, 268-271

24. Kaneko, S.; Yamamoto, K.; Kinoshita, M.; Wakabayashi, Y.; Iida, Y. Design and Operation Experience of a $1000 \mathrm{MW}$ Ultra Supercritical Coal Fired Bojler with Steam Condition of 25.4 Mpa 604/602 ${ }^{\circ}$ C. Mitsubishi Heavy Ind. Ltd. Tech. Rev. 1999, 36, 61-65.

25. Yano, T.; Sakai, K.; Kiyama, K.; Okada, O.; Ochi, K. Updated low $\mathrm{NO}_{x}$ combustion technologies for boilers. Available online: http:/www.hitachipowersystems.us/supportingdocs/forbus/hpsa/ technical_papers/Mega2003.pdf(accessed on 14 March 2011).

26. Kimura, H.; Matsuda, J.; Sakai, K. Latest experience of coal fired supercritical sliding pressure operation boiler and application for overseas utilities. Available online: http://www.bhk.co.jp/ english/technical/pdf/pge2003paper_blr.pdf (accessed on 17 March 2011).

27. Kajitani, S.; Hara, S.; Matsuda, H. Gasification rate analysis of coal char with a pressurized drop tube furnace. Fuel 2002, 81, 539-546.

(C) 2011 by the authors; licensee MDPI, Basel, Switzerland. This article is an open access article distributed under the terms and conditions of the Creative Commons Attribution license (http://creativecommons.org/licenses/by/3.0/). 